\title{
Silmujen solurakenteiden muutosten ja kukka-aiheiden kehittymisen yhte- ys vadelman (Rubus idaeus L.) kylmänkestävyyteen
}

\author{
Paula Lilja ja Pauliina Palonen \\ Soveltavan biologian laitos, PL 27,00014 Helsingin yliopisto, Paula.Lilja@helsinki.fi
}

\section{Johdanto}

Vadelmanviljelyn suurin ongelma Suomessa on satomäärien suuri vuotuinen vaihtelu, joka vaikeuttaa tuotannon suunnittelua, koneellistamista sekä kotimaisen vadelman hyödyntämistä teollisuudessa. Ongelman aiheuttajana on viljelyssä olevien vadelmalajikkeiden Suomen olosuhteisiin nähden heikko talvenkestävyys. Yksi mahdollinen keino talvenkestävien vadelmalajikkeiden löytämiseksi voi olla solurakenteiden muutosten tutkiminen karaistumisen aikana. Näitä muutoksia tutkimalla voi olla mahdollista löytää rakenteellinen piirre, joka kertoo vadelmalajikkeen hyvästä karaistumiskyvystä. Karaistumiskyky on yksi talvenkestävyyteen keskeisesti vaikuttavista tekijöistä. Voidaan olettaa, että kylmänkestävällä lajikkeella kylmänkestävyyden paranemiseen tähtäävät solurakenteiden muutokset ovat voimakkaampia kuin muutokset kylmälle aran lajikkeen soluissa tai, että kylmänkestävän lajikkeen soluissa tapahtuu muutoksia, joita ei tapahdu kylmälle aran lajikkeen soluissa.

Solurakenteiden muutoksia karaistumisen aikana ei ole aikaisemmin tutkittu vadelmalla, joten tutkimuksen tavoitteena oli ensinnäkin selvittää millaisia muutoksia vadelmansilmujen soluissa tapahtuu karaistumisen aikana. Silmut valittiin tutkimuksen kohteeksi, koska ne ovat vadelman kylmälle arin osa. Kahta kylmänkestävyydeltään erilaista lajiketta vertaamalla pyrittiin löytämään kylmänkestävyyden kannalta olennainen solurakenteen muutos, joka selittäisi toisen lajikkeen paremman kylmänkestävyyden. Lisäksi tavoitteena oli selvittää, miten vadelman kukka-aiheiden kehittyminen etenee Suomen oloissa, onko kukka-aiheiden tai silmun tyven johtosolukon kehityksessä eroja lajikkeiden välillä ja onko kukka-aiheiden kehitysasteen ja kylmänkestävyyden välillä havaittavissa yhteyttä. Solurakenteiden muutoksia tarkasteltiin elektronimikroskopian avulla ja kukka-aiheiden sekä silmun johtosolukon kehittymistä valomikroskooppinäytteistä. Tutkimus tehtiin osana Soveltavan biologian laitoksen projektia 'Vadelman ja mansikan talvenkestävyyden parantaminen lajikevalinnan ja viljelytekniikan keinoin'. Tutkimuksessa haettiin vastauksia seuraaviin kysymyksiin:

- Miten vadelman kukka- ja lehtiaiheiden solurakenteet muuttuvat kylmänkestävyyden muuttuessa?

- Onko syksyllä karaistumisvaiheessa tai talven aikana havaittavissa eroja solurakenteessa kylmänkestävän ja kylmälle aran lajikkeen välillä?

- Voidaanko jokin piirre solurakenteessa yhdistää kylmänkestävyyteen siten, että sitä voidaan pitää hyvästä karaistumiskyvystä kertovana piirteenä?

- Onko kukka-aiheiden kehityksessä eroja kahden kylmänkestävyydeltään erilaisen lajikkeen välillä?

\section{Aineisto ja menetelmät}

Tutkittavat vadelmalajikkeet olivat kylmänkestävä 'Ville' ja kylmänarka 'Haida', joita oli saatavilla Kiteen Vadelma Ky:n viljelmältä Kiteeltä. Näytteet otettiin ennen karaistumisen alkua 5.9.2000, karaistumisen aikana 12.11.2000 ja karaistuneen tilan ollessa oletettavasti syvimmillään 29.1.2001. Näytteiksi otettiin kerralla 11-12 talvehtivaa versoa kumpaakin lajiketta. Versojen keskiosasta otettiin valoja elektronimikroskoopinäytteiksi silmut 12-15 kärjestä laskettuna. Silmujen 9-11 välinen osa sekä verson alaosa (silmut 16-21) käytettiin kylmätestiin, jonka avulla määritettiin eri lajikkeiden kylmänkestävyys eri kasvinosien LT50-arvona. Kylmätestissä näytteet pakastettiin ohjelmoitavalla pakastuskaapilla, jonka lämpötila laski kolme astetta tunnissa ja pysyi kussakin testilämpötilassa puolen tunnin ajan. Testilämpötiloja oli syyskuun pakastuksessa seitsemän ja marraskuussa sekä tammikuussa kahdeksan, ja ne vaihtelivat välillä -3 - - 41 C. Kutakin testilämpötilaa kohden oli kaksitoista yhden silmun mittaista versonpalaa kumpaakin lajiketta. Näytteet sulatettiin $0 \mathrm{C}$ :ssa, minkä jälkeen niitä pidettiin huoneenlämmössä kahden viikon ajan. Tämän jälkeen kylmäkäsittelyn aiheuttamat vauriot arvioitiin stereomikroskoopin avulla silmun tyven ja verson johtosolukoista sekä kukka-aiheista. Näytteille annettiin arvot 0-2 solukon ruskettumisen mukaan. Täysin elävä sai arvon 0 ja täysin kuollut arvon 2 . Arvo 1 annettiin vaurioituneille, mutta toipumiskykyisille näytteille. Tilastollisia analyysejä varten arviointiasteikko muutettiin kaksiluokkaiseksi, jolloin eläviin näytteisiin laskettiin myös alunperin arvon 1 saaneet näytteet. Kummankin lajikkeen versoille, silmun tyven johtosolukolle ja kukkaaiheille laskettiin LT50-arvot logit-malleja käyttäen; myös lajikkeiden kylmänkestävyyseroja testattiin logit-malleilla. 
Valomikroskopointia varten silmuista valmistettiin parafiinileikkeitä, jotka käsiteltiin kestopreparaateiksi. Fiksatiivina käytettiin formaldehydiä, etikkahappoa ja $50 \%$ tai $70 \%$ etanolia sisältävää FAA:ta. Fiksatiivikäsittely kesti vuorokauden huoneenlämmössä. Näytteet dehydroitiin nousevassa etanolisarjassa ja niihin imeytettiin butanolin kautta tukiaine, parafiini, johon näytteet valettiin. Imeytys kesti 60 C:ssa 4-10 päivää. Tavoitteena oli saada kaikilta näytteenottokerroilta näytteet neljästä silmusta lajiketta kohti, mikä onnistuikin lukuunottamatta syyskuun 'Haida'-näytteitä, joista saatiin leikkeitä vain kahdesta silmusta näytteiden repeilyn vuoksi. Lasille siirretyt $10 \mathrm{~mm}$ paksuiset parafiinileikkeet kuivattiin $40 \mathrm{C}:$ ssa, niistä poistettiin parafiini ksyleenin avulla ja ne värjättiin safraniinikristalliviolettivaaleanvihreällä, safraniini-fast greenilla tai pelkällä safraniinilla. Värjäyksen jälkeen näytteet käsiteltiin sulkuaineella, kanadabalsamilla.

Elektronimikroskopointia varten silmuista pyrittiin preparoimaan näytteeksi vain kukkaaiheet ja sisimmät lehtiaiheet. Fiksatiivina käytettiin $2,5 \%$ glutaraldehydiä $0,1 \mathrm{M}$ natriumfosfaattipuskurissa $(\mathrm{pH} \mathrm{7,2)} \mathrm{ja} 1 \%$ veteen laimennettua osmiumtetroksidia. Glutaraldehydissä näytteet olivat kaksi tuntia ja osmiumtetroksidissa tunnin. Osmiumtetroksidikäsittelyn jälkeen näytteet dehydroitiin nousevassa etanolisarjassa ja imeytettiin tukiaineena käytettyyn muoviin, johon näytteet valettiin. Syyskuussa käytettiin Epon LX 12-muovia, mutta sen huonojen leikkausominaisuuksien vuoksi marraskuussa siirryttiin Spurrin muoviin. Osmiumtetroksidikäsittelystä lähtien näytteiden valmistus ja kuvaaminen tapahtui Helsingin yliopiston Biotekniikan instituutin elektronimikroskopian yksikössä. Muoviblokeista leikattiin 50-60 nm paksuja leikkeitä. Jokaisen näytteenottokerran näytteist,, leikattiin silmun pituussuuntaisia leikkeitä ja tammikuun näytteistä poikittaissuuntaisia leikkeitä. Leikkeet värjättiin uranyyliasetaatilla (käsittely $30 \mathrm{~min}$ ) ja lyijysitraatilla (1,2 min). Joka näytteenottokerralta tarkasteltiin 1-2 silmua lajiketta kohti.

\section{Tulokset ja tulosten tarkastelu Kylmänkestävyys}

'Villen' kylmänkestävyys oli lähes kaikilla näytteenottokerroilla ja kaikissa kasvinosissa odotusten mukaisesti parempi kuin 'Haidan' (Taulukko 1). Vain tammikuussa 'Villen' ja 'Haidan' kukka-aiheiden kylmänkestävyydessä ei ollut eroja. Kasvinosista versot olivat pääsääntöisesti kaikkein kestävimpiä ja silmun tyven johtosolukot arimpia. Suurin muutos kylmänkestävyydessä tapahtui syyskuun ja marraskuun välillä. Marraskuussa versojen mahdollista kylmänkestävyyseroa ei saatu selville, koska lähes kaikki näytteet kestivät enemmän kylmää kuin $-27 \mathrm{C}$, joka oli alhaisin testilämpötila. Tarpeeksi alhaisia testilämpötiloja ei osattu valita, sillä vuoden 2000 syksy ja vuoden 2001 tammikuu olivat poikkeuksellisen lämpimiä.

Taulukko 1. 'Villen' ja 'Haidan' versojen, silmun tyven johtosolukon ja kukka-aiheiden LT50-arvot eri näytteenottokerroilla. Tähdellä (*) merkityissä kohdissa lajikkeiden välinen kylmänkestävyysero oli tilastollisesti merkitsevä $(\mathrm{p}<0,05)$.

\begin{tabular}{lllll}
\hline & & \multicolumn{3}{c}{$\mathrm{LT}_{50^{-} \text {-arvo }\left({ }^{\circ} \mathrm{C}\right)}$} \\
\cline { 3 - 5 } Näytteenottoaika & Lajike & Versot & Silmun tyvi & Kukka-aiheet \\
\hline \multirow{2}{*}{5.9 .2000} & Haida & $-10,2^{*}$ & $-9,0^{*}$ & $-10,0^{*}$ \\
\multirow{2}{*}{12.11 .2000} & Ville & $-12,2$ & $-10,5$ & $-13,8$ \\
& Haida & $<-27$ & $-21,8^{*}$ & $<-27^{*}$ \\
2.1 .2001 & Ville & $<-27$ & $<-27$ & $<-27$ \\
& Haida & $-30,8^{*}$ & $-27,0^{*}$ & $-26,2$ \\
& Ville & $-34,8$ & $-31,4$ & $-27,5$ \\
\hline
\end{tabular}

\section{Kukka-aiheiden ja silmun johtosolukon kehittyminen}

Syyskuun alussa otetuissa näytteissä oli molemmilla lajikkeilla havaittavissa päätekukan verholehtien aiheet ja laajentunut kukkapohjus suurimmassa osassa tutkittuja näytteitä. Marraskuussa 'Haidan' kukka-aiheissa oli havaittavissa terälehtien aiheet, mutta 'Villellä' niitä ei havaittu yhdessäkään tarkastellussa näytteessä. Tarkasteltujen näytteiden perusteella voitiin siis päätellä, että kylmälle aralla 'Haidalla' kukka-aiheet olivat marraskuussa pidemmällä kehityksessään kuin 'Villellä', jonka kukka-aiheet 
olivat marraskuussa kestävämpiä. Marraskuun ja tammikuun näytteenottokertojen välillä kummankaan lajikkeen kukka-aiheissa ei tapahtunut kehitystä. Kukka-aiheiden selviytymiseen alhaisissa lämpötiloissa vaikuttaa ennen kaikkea niiden kyky alijäähtyä syvään, ja pienen solukoon tiedetään edesauttavan alijäähtymistä (Ashworth 1982). Mitä pidemmälle kukka-aiheet kehittyvät ennen talvea, sitä suuremmiksi solut ehtivät kasvaa, jolloin niiden riski menettää alijäḧhtymiskykynsä ja vaurioitua pakkasessa suurenee. Tämän perusteella voidaan päätellä, että lajikkeet, joilla kukka-aiheet kehittyvät pidemmälle ennen talven tuloa, ovat arempia kylmälle kuin lajikkeet, joilla kehitys pysähtyy syksyllä aikaisempaan vaiheeseen. Toisaalta karhunvatulla ei kukka-aiheiden kehitysvaiheen ja kylmänkestävyyden välillä ole havaittu olevan yhteyttä (Warmund ym. 1992).

Tarkasteltujen näytteiden perusteella vaikuttaa siltä, että vadelman kukka-aiheiden muodostuminen alkaa Suomessa aikaisemmin kesällä, tai se etenee nopeammin alkusyksyn aikana kuin esimerkiksi Iso-Britanniassa, missä kukka-aiheiden kehittymistä on aikaisemmin tutkittu (Williams 1959). Tiedetään, että alhainen lämpötila edistää kukka-aiheiden kehittymistä vadelmalla (Vasilakakis ym. 1979), minkä perusteella on luonnollista olettaa, että kukka-aiheiden kehittyminen on Suomessa nopeampaa kuin lämpimämmässä ilmastossa. Suomen alhaisemmat lämpötilat ovat todennäköisesti syyn,, myös siihen, ett,, tutkituilla lajikkeilla kukka-aiheiden kehitys pysähtyi aikaisempaan kehitysvaiheeseen kuin mitä on havaittu Iso-Britanniassa tehdyissä tutkimuksissa (Williams 1959).

Silmun tyven johtosolukossa ei tapahtunut muutoksia kokeen aikana, eikä siinä ollut havaittavissa eroja lajikkeiden välillä, joten erot tässä suhteessa eivät olleet syyn,, 'Villen' kukka-aiheiden parempaan kylmänkestävyyteen. Valomikroskooppinäytteistä havaittiin, että johtojänteen puuosan putkiloelementtien kehitys vadelman kukka-aiheiden tai silmun tyven yläosan johtosolukossa ei ala vielä keskitalvella. Jos putkiloelementit kehittyisivät toimiviksi jo keskitalvella, olisivat kukka-aiheet vaarassa menettää kykynsä alijäähtyä syvään jo kovimpien pakkasten aikaan, sillä persikalla (Prunus persica L.) tehdyissä tutkimuksissa on havaittu, että vesi tai jää eivät liiku esijällen soluja pitkin kukintoon ja tämä ylläpitää kukka-aiheiden kykyä alijäähtyä syvään siihen asti, kunnes putkiloelementit kehittyvät toimiviksi keväällä (Ashworth 1984).

\section{Solurakenne}

Sekä 'Villen' että 'Haidan' kukka- ja lehtiaiheiden solurakenne pysyi pääpiirteissään muuttumattomana karaistumisen aikana. Solujen rakenne oli hyvin samankaltainen eri näytteenottoajankohtina, eikä myöskään kukka- ja lehtiaiheiden solujen rakenteissa ollut havaittavissa suuria eroja toisiinsa verrattuna, vaikka lehtiaiheiden solut olivatkin yleensä suurempia. Tutkittujen vadelmalajikkeiden silmujen soluissa ei havaittu samanlaisia kylmänkestävyyden lisääntymiseen liittyviä rakenteellisia muutoksia kuin versojen solukoissa on havaittu (Pomeroy ja Siminovitch 1971, Niki ja Sakai 1981). Kukkaaiheiden osalta tämä on ymmärrettävää, koska vadelman kukka-aiheet alijäähtyvät pakkasessa, mutta versoissa muodostuu oletettavasti jäätä solujen ulkopuolelle. Lehtiaiheiden kylmänkestävyysmekanismi on kuitenkin samanlainen kuin versojen, joten niissä olettaisi tapahtuvan samanlaisia muutoksia kuin versojen solukoissa, mikäli muutokset todella ovat edellytyksenä kylmänkestävyyden kehittymiselle.

Kukka- ja lehtiaiheiden soluissa oli yleensä soluun kokoon nähden suuri tuma, useita pieni,, vakuoleja ja runsaasti eri soluelimiä: plastideja, mitokondrioita, rakkuloita muodostavia diktyosomeja ja endoplasmakalvoston rakenteita. Tuman suuri koko, suuren keskusvakuolin puuttuminen ja eri soluelinten runsaus ovatkin kasvusolukon soluille tyypillisiä piirteitä (Robards 1970). Endoplasmakalvoston ja rakkuloita muodostavien diktyosomien esiintymistä soluissa pidetään yleensä merkkinä jostakin aineenvaihduntaan liittyvästä toiminnasta, joten ilmeisesti lepotilan aikanakaan silmujen aineenvaihdunta ei ole täysin pysähdyksissä. Rakkuloiden muodostuminen diktyosomeista on Robardsin (1970) mukaan tyypillistä aktiivisesti jakautuville soluille sekä soluille, joissa muodostuu uutta soluseinää. Todennäköisesti silmujen soluissa muodostuu uutta soluseinää ainakin syksyllä, sillä haavan (Populus deltoides Bartr. Ex Marsh) k,rkisilmun soluissa soluseinien on havaittu olevan paksumpia lepotilan aikana kuin kasvuvaiheessa (Jian ym. 1997). Samanlaista soluseinien paksuuntumista tapahtui ilmeisesti myös tutkituilla vadelmalajikkeilla, sill,, syyskuussa 'Haidan' kukkapohjuksen soluissa oli ohuet soluseinät, ja marraskuun näytteessä saman solukon solut olivat paksumpiseinäisiä. Myös 'Villen' kukkalapakon soluissa soluseinät näyttivät paksuuntuneen syyskuun ja marraskuun näytteenottokertojen välillä. Solurakenteiden vertailua eri näytteiden välillä vaikeutti se, että esimerkiksi kukka-aiheista otetut kuvat eivät kaikki ole juuri samasta kohtaa kukkalapakkoa. Tähän oli syynä näytteiden repeily leikattaessa ja se, ettei silmuista useinkaan onnistuttu saamaan leikkeitä, joilla koko kukinnon aihe ja sitä lähinnä olevat nuorimmat lehtiaiheet olisivat näkyneet. 
'Haidan' kukkapohjuksen soluissa oli marraskuussa todennäköisesti enemmän tärkkelysjyväsiä ja rasvapisaroita kuin syyskuussa. Myös 'Villellä' rasvapisarat näyttivät lisääntyneen syyskuun ja marraskuun näytteenottokertojen välillä sekä kukka- että lehtiaiheissa. 'Villellä' tärkkelysjyväsiä oli runsaasti osassa kukkalapakon soluja myös syyskuussa, joten niiden lisääntymistä syyskuun ja marraskuun välillä oli vaikea arvioida. Aikaisemmin on havaittu tärkkelysjyväsiä ja rasvapisaroita kertyvän lepotilassa olevan pajun (Salix sp. L.) (Berggren 1985) ja lehmuksen (Tilia europaea L.) (Cragg ja Willison 1980) hankasilmujen soluihin. Pelkästään tärkkelysjyväsiä kertyy lepotilassa oleviin haavan kärkisilmujen soluihin (Jian ym. 1997).

\section{Johtopäätökset}

Kylmänkestävällä vadelmalajikkeella kukka-aiheiden kehittyminen oli jäljessä kylmälle aran lajikkeen kehityksestä. Pidemmälle kehittyneet kukka-aiheet ovat siis todennäköisesti kylmälle arempia kuin vähemmän kehittyneet. Suomen olosuhteissa vadelman kukka-aiheiden kehitys on alkusyksystä pidemmällä, mutta päättyy aikaisemmin syksyllä kuin lämpimämmässä ilmastossa. Todennäköisesti Suomen alhaisemmat lämpötilat, jotka edistävät kukka-aiheiden kehittymistä kesällä ja alkusyksystä, saavat talven tullessa aikaan kehityksen pysähtymisen.

Vadelmansilmujen solurakenteessa ei tapahtunut samanlaisia kylmänkestävyyden lisääntymiseen liittyviä muutoksia kuin versojen solukoissa, vaan kukka- ja lehtiaiheiden solurakenne vastasi käsityksiä kasvusolukon solujen rakenteesta myös lepotilan aikana. Todennäköisesti rasvapisarat lisääntyivät ja soluseinät paksuuntuivat vadelmansilmujen soluissa syksyn aikana. Jatkossa olisikin selvitettävä, liittyvätkö nämä aikaisemmin muilla lajeilla raportoidut muutokset kylmänkestävyyden lisääntymiseen vai lepotilaan.

\section{Kirjallisuus}

Ashworth, E.N. 1982. Properties of peach flower buds which facilitate supercooling. Plant Physiology 70: 1475-1479.

Ashworth, E.N. 1984. Xylem development in Prunus flower buds and the relationship to deep supercooling. Plant Physiology 74: 862-865.

Berggren, B. 1985. Ultrastructure of dormant buds of Salix sp. in early winter. Nordic Journal of Botany 4: 475488.

Cragg, F.J. \& Willison, J.H.M. 1980. The ultrastructure of quiescent buds of Tilia europaea. Canadian Journal of Botany 58: 1804-1813.

Jian, L, Li, P.H., Sun, L. \& Chen, T.H.H. 1997. Alterations in ultrastructure and subcellular localization of $\mathrm{Ca} 2+$ in poplar bud cells during the induction of dormancy. Journal of Experimental Botany 311: 1195-1207.

Niki, T. \& Sakai, A. 1981. Ultrastructural changes related to frost hardiness in the cortical parenchyma cells from mullberry twigs. Plant \& Cell Physiology 22: 171-183.

Pomeroy, M.K. \& Siminovitch, D. 1971. Seasonal cytological changes in secondary phloem parenchyma cells in Robinia pseudoacacia in relation to cold hardiness. Canadian Journal of Botany 49: 787-795.

Robards, A.W. 1970. Electron Microscopy and Plant Ultrastructure. McGraw-Hill Publishing Company, Lontoo. $298 \mathrm{~s}$.

Vasilakakis, M.D., Struckmeyer, B.E. \& Dana, M.N. 1979. Temperature and development of red raspberry flower buds. Journal of the American Society for Horticultural Science 104: 61-62.

Warmund, M.R., Takeda, F. \& Davis, G.A. 1992. Supercooling and extracellular ice formation in differentiating buds of eastern thornless blackberry. Journal of the American Society for Horticultural Science 117:

941-945.

Williams, I.H. 1959. Effects of environment on Rubus idaeus L. IV. Flower initiation and development of the inflorescence. Journal of Horticultrural Science. 34: 219-228. 